Home services for children and adolescents: feedback effects, reflections, and current challenges

Geralda Luiza de Miranda

Universidade Federal de Minas Gerais / Departamento de Ciência Política

Belo Horizonte / MG — Brazil

The objective of the study is to investigate, through a historical and institutional perspective, the historical development and current configuration of the Institutional Care Service for Children and Adolescents at risk. It is argued that, by favoring the development of certain skills at the expense of others, previous decisions have influenced current decisions, explaining the difficulty of changing the course of policy. The analysis shows that choices made in the Vargas Era undermined the implementation of innovations established by the Código de 1979 and the Estatuto da Criança e do Adolescente (ECA) (1990) up until the mid-2000s when the bureaucracy of state social assistance was strengthened. The empirical data used are found in the Censo Suas 2014 and the regulations that, from the early twentieth century, have been structured in child and adolescent social assistance policies.

Keywords: children and adolescences; social assistance; ECA; Children’s Code; institutional care.

\title{
Serviço de Acolhimento Institucional para Crianças e Adolescentes: feedback effects, inflexões e desafios atuais
}

O objetivo do estudo é investigar, da perspectiva do institucionalismo histórico, a evolução histórica e a configuração atual do Serviço de Acolhimento Institucional para Crianças e Adolescentes em situação de risco. Argumenta-se que decisões prévias, por favorecerem o desenvolvimento de certas capacidades estatais em detrimento de outras, influenciam decisões correntes, explicando a dificuldade de mudança no curso das políticas. A análise mostra que escolhas feitas na Era Vargas prejudicaram a implementação de inovações do Código de Menores de 1979 e do Estatuto da Criança e do Adolescente (ECA), de 1990, até meados da década de 2000, quando a burocracia estatal na área da assistência foi fortalecida. A empiria utilizada são os dados do Censo Suas 2014 e as normativas que têm estruturado, desde o início século XX, as políticas de assistência social e de atenção à criança e ao adolescente.

Palavras-chave: criança e adolescente; assistência social; ECA; Código de Menores; acolhimento institucional.

\section{Servicio de Acogimiento Institucional para Niños y Adolescentes: efectos de retroalimentación, inflexiones y retos actuales}

El objetivo del estudio es investigar, de la perspectiva del institucionalismo histórico, el desarrollo histórico y la configuración actual del Servicio de Acogimiento Institucional para los Niños y Adolescentes en situación de riesgo. Se argumenta que, al favorecer el desarrollo de ciertas habilidades a expensas de la otra, las decisiones anteriores influyen en las decisiones actuales, lo que explica la dificultad de cambio en el curso de la política. El análisis muestra que las decisiones tomadas en el estado Vargas minaron la aplicación de las innovaciones establecidas por el Código de Menores de 1979 y el Estatuto da Criança e do Adolescente (ECA), de 1990, hasta mediados de 2000, cuando se fortalece la burocracia estatal de asistencia social. El empírica utilizada son los registros del Censo Suas 2014 y las normas que se estructuran a partir de principios del siglo XX, las políticas de asistencia social y la atención a los niños y adolescentes.

Palabras clave: niño y adolescente; asistencia social; ECA; Código del Menor; acogimiento institucional. 


\section{INTRODUCTION}

Previous policies influence the options that decision-makers take into account when designing new policies. Under this assumption, previous policies should be viewed as independent variables, among others so defined. An example is found in the formal institutions which set the rules for such decision-making process (Skocpol, 1992; Thelen and Steinmo, 1992; Weir and Skocpol, 1999). When exploring the implications of this general assumption, that is, 'policies produce politics', Pierson identified such influence in two different mechanisms. The first is found in the access to political resources and the promotion of political incentives granted to governmental elites, interest groups and mass publics which is made available by decisions previously made. The second is found in the effects that the knowledge of such decisions have on the strategic behavior of the political actors involved (Pierson, 1993:595-598).

According to Pierson (1993), the first mechanism - resources and incentives granted to certain political actors - operates as follows: previous policies may, first, contribute to the creation of given managerial capabilities, thus restricting the development of organizational alternatives, which results in that decisions made by politicians and bureaucrats are generally bounded by the existing capabilities. Pierson expands the argument by pointing to the increasing influence that interest groups benefitted by privileged access to the decision-making process and/or to financial resources may acquire in the formulation of given policies. According to this analytical approach, previous policies may be seen as formal institutions, "influencing the allocation of economic and political resources, modifying the costs and benefits associated with alternative political strategies, and consequently altering ensuing political development" (Pierson, 1993:596).

However, the actual history of policies gives evidence to the dynamics of path dependence, identified in feedback effects, as well as to the introduction of innovation and institutional changes. The latter may represent real turning points leading to new paradigms even in the absence of radical changes (Hall, 1993).

Historical institutionalism emphasizes the context in the analysis of institutional dynamics. One privileged context is found in situations of crisis, which create opportunities for change and a favorable climate for the debate of new institutional arrangements (Gourevith, 1986). This theoretical approach also emphasizes different contexts of change, among others the following: a) changes in the socioeconomic or political context leading to the actualization of latent institutions; b) changes in the socioeconomic environment or in the balance of power leading to the revitalization of old institutions adapted to performing new functions; $c$ ) changes in goals or strategies within stable institutional environments. Historical institutionalism also identifies topical changes caused by political conflicts or by the persistent adherence to conventional strategies by given actors performing political roles within stable institutional environments (Thelen and Steinmo, 1992). Skocpol (1992) and Pierson (1993) point out to a fourth factor of institutional dynamics, that is, the development of public bureaucracies authorized to make decisions and in charge of allocating managerial and monetary resources to implement policies designed with the participation of social groups.

This paper presents the history and actual design of policies adopted in Brazil aiming at the provision of social protection to children and adolescents, focusing especially on the services connected to institutional shelter (acolhimento institucional), previously defined as public housing (abrigamento). The analysis is based on the assumption that decisions made in the past influence present decision-making because they favored the development of certain capabilities, thus restricting the actualization of others. The resulting institutional context does not favor the adoption of alternative policy options. The research offer empirical evidence both to identify institutional inertia resulting 
from mechanisms of feedback effects and points of greater or lesser changes in the courses of action. The first kind of evidence is found in the political directives adopted in the Vargas years, which reaffirmed and expanded the 1927 law detailing the State responsibilities in the care and protection of minors (Código de Menores or Juvenile Code). This law and further legislation on the subject dealt with public financing of social assistance to minors and the access to public funding for private organizations in charge of providing connected social services. This new institutional context granted to these organizations the right to participate in decision making processes concerning social assistance to minors. The second kind of evidence is found in the impact of social movements active in the last years of the 1970's and throughout the 1980's, aiming at denouncing the crisis of the political paradigm orienting the actions of governments in the area of protection to minors. The arguments and goals of those movements played a major role in shaping new policy alternatives and in the empowerment of new political actors. Progress in legislation occurred in 1979 with the new Juvenile Code and in 1990, when the National Congress approved the law number 8.069, the Children and Adolescent Statute (ECA). The second important research finding shows that the effective impact of the new legislation on the management and resources allocated to policies of social protection for this public are associated with the consolidation of professional bureaucracies at the federal level of government and the decreasing of monetary payments to private organizations. At this point, it is worthwhile remembering that innovations embodied in the 1979 law (Juvenile Code) were prevented from prospering because of resilient organizational features and practices established during the Vargas years. The innovations embodied in the Children and Adolescent Statute (ECA) took almost twenty years to be implemented. It was already 2009 when the bureaucracy and technical staff of the Social Assistance National System (Sistema Único de Assistência Social - Suas) became totally able to secure and manage the required material, financial and cognitive resources to accomplish its goals.

The empirical reference of the analysis developed in this paper is found in resolutions approved by public offices responsible for the area of social protection for children and adolescents and in the 2014 Suas census data (Censo Suas - 2014). The analysis is developped in three sections, besides this introduction and the conclusion. The first section presents the initial design of the institutional framework for the provision of social protection for children and adolescents, according to decisions made by public authorities. The second section deals with the institutional contexts that made possible the implementation of public shelter services. The analysis focuses on feedback effects of decisions made during the Vargas years, the military regime and the first decade after the return to the democratic regime (years 1990). The third section describes the present institutional design for the provision of public shelter services. The analysis focuses on changes dating back to the years 2000 and points to present challenges.

\section{THE ORIGINAL DESIGN FOR THE PROVISION OF INSTITUTIONAL SHELTER SERVICES}

The principles of Brazilian policy aiming at protecting children and adolescents were first established in the 1927 (Decree 17.943-A, later known as Juvenile Code). ${ }^{1}$ The decree established rights pertaining to the social strata identified as "neglected minors and juvenile delinquents", the rights to life, health and identity. According to articles 1,2 and 17, the State was responsible for monitoring their effective realization and for providing assistance and protection to individuals.

The enactment of the 1927 Juvenile Code was the culmination of a major debate focusing on issues related to social neglect of children. According to Soares (2003), since the beginning of the

\footnotetext{
${ }^{1}$ The decree 17.943-A incorporated elements of previous legislation, that is, the 1923 Decree 16.772, and the 1926 Decree 5.083.
} 
twentieth century, the political and legal aspects of those issues grew in visibility in national and international circles. At the international level, three initiatives were decisive in expanding the debate: first, the 1911 International Children Congress held in Paris, which publicized the growing concern with childhood issues; second, the 1924 League of Nations' resolution to subscribe to the Genova Declaration, that is, the Declaration of Children's Rights, enacted by the International Union for the Protection of Children; third, the Minimum Admission Age in Factories Convention, approved in the 1919 International Labor Conference, sponsored by the International Labor Organization (ILO). ${ }^{2}$

At the national level, the debate confronted two groups, one stressing the need to protect children, holding to ideas and principles which inspired the Genova Declaration and the ILO Convention, the other stressing the need to protect society against juvenile delinquency, then (and seemingly even today) interpreted as a consequence of poverty. According to Rizzini and Rizzini (2004), the terms of the debate could be reduced to propositions aiming at "saving the children" and to propositions aiming at "saving Brazil" from a social malaise. These two concerns set the guidelines for the legislation consolidated in the Decree n 17.943-A. According to Rizzini and Rizzini, the dominant concern was "saving Brazil".

Rizzini and Rizzini's evaluation of the social and political implications of the normative framework then enacted is based on the identification of three polemical features in the conception of public care designed in the provisions set in the 1927 Juvenile Code: first, the primacy given to internment institutions, the existing solution prevailing in Brazil for the care of neglected children, which became the outstanding public option to provide education and care for poor children; second, the adoption of police jargon, common at that time, to identify child and adolescent behavior (vagrant, indecent, delinquent); third, the adherence to principles of social hygiene and morality. Three other features established by the decree, related to the organizational structure and the management of the internment service to be provided by the State should also be stressed. First, the 1927 Juvenile Code did not deal with the duration of internment or actions aiming at planning the return of children and adolescents to family life. The result of this omission was the retention of interns until the age of eighteen. Second, the internment institutions were designed as "total institutions", that is, they were made responsible for all aspects of the care that should be granted to interns, including medical assistance, education and training for the labor market. Third, during the Vargas years, prevailed the decision to assign the provision of internment mainly to private organizations. This policy orientation turned out to be a major obstacle to later policy changes, for it did not favor the early formation of a professional bureaucracy in this field of public action and contributed to the empowerment of private actors in decision-making processes that followed.

Despite these shortcomings, the 1927 Juvenile Code represented real improvements benefiting Brazilian children and adolescents. Some of them deserve mention: first, the termination of any socially accepted form of abandoning unwanted babies in public places (sistema de rodas). ${ }^{3}$ The first article of the new law defined assistance and protection to neglected and delinquent children, boys and girls under 18 years, to be a permanent responsibility of the State; second, the State was given authority to intervene in family affairs and labor relations in aspects concerning treatment given to children; third, the criminal legal age was raised; trial and internment procedures were adapted to conduct the cases of delinquent children under 14 years of age, an innovation in prevailing judicial regulations. ${ }^{4}$

\footnotetext{
${ }^{2}$ Only in 1934 the Brazilian government ratified this convention. The corresponding decree was enacted in 1935.

${ }^{3}$ The hospitals sponsored by the Catholic Church (Santas Casas) afforded this option to mothers who could leave the unwanted child in a moving door, opening to the interior of the house, where nuns would take care of the baby. The mechanism was known as "wheel of the unwanted or exposed" ("roda dos expostos ou enjeitados").

${ }^{4}$ The 1830 Legal Code included formal punishment for children from 9 to 14 years found in criminal behavior, if their knowledge of the social negative meaning of the act could be proved.
} 
At that time, the prescribed "surveillance" was limited to monitoring the compliance to rules defined in the Juvenile Code within families, work places and social institutions. Child labor should be prevented; unaccepted parental or tutorial behavior, such as negligence, abuse, cruelty, exploitation and perversity should result in destitution of parental or tutorial power (nowadays recognized as family power). This kind of public control was already detailed in previous laws. ${ }^{5}$ Public surveillance extended to social institutions in charge of providing assistance to children and adolescents.

To guarantee the provision of social assistance and care to children and adolescents the 1927 Code inaugurated the cooperation of federal organizations and private institutions. The federal structure comprised the Minor and Juvenile Court of the Federal District, the National Council for Assistance and Protection of Minors, one internment house and correctional facilities. The private structure comprised schools, boarding houses and shelter homes, eligible for receiving federal subventions.

The members of the National Council were chosen among managers of the private institutions, lawyers nominated by the National Association of Lawyers and doctors nominated by the National Academy of Medicine and the National Office of Public Health. It also included members representing the Ministry of Justice and Domestic Affairs.

There were two kinds of correctional facilities, one in charge of providing regular education, the other in charge of reeducating (or reforming) the children and adolescents. Up to 300 girls were the public of the first kind, where physical, moral, literary and professional education was offered. Up to 200 boys were the public destined to the second kind. Two existing schools were chosen for this purpose (Quinze de Novembro and João Luiz Alves). The internment house was established in 1932, when the Instituto Sete de Setembro was adapted to receive 400 boys and 150 girls.

Those facilities were financed by the federal government; private institutions were authorized to manage them. According to the 1927 Code, the management model then adopted kept the interns in strict routines, allowing few opportunities of external contacts. The staff included professionals, among them doctors and teachers. There were rules to control visitors, who could not offer presents or other materials to the interns. The whole design of the Juvenile Code might endorse Rizzini's view (2007) that the policy aimed not only at "saving Brazil" from delinquents, but also at "saving the children" from the moral degradation and vices so common in the environment of poverty in which they were born.

It was ten years before the required organizational structure for the full implementation of the policy was actually established under Vargas's government. The action began with the 1938 Decree-Law 525 , which regulated federal subventions to private institutions and inaugurated a public forum to coordinate the policies of social assistance, the National Council for Social Service (CNSS). This forum was formed by four representatives of the private institutions, the judge in charge of children and adolescents' affairs e two representatives of the Ministry of Education and Health. It was actually a consultation body focusing on social services provided by the State in partnership with private institutions, arbitrating the amount of public money to be transferred to those institutions.

During the 1940's, by means of the 1940 Decree-Law 2.014 and of the 1941 Decree-Law 3.799, Vargas government expanded and reorganized the bureaucratic structure of the social protection for children and adolescents. There were changes in the procedures related to the internment services. These changes strengthened the public capability in this field of policy, but the influence of the private actors was also strengthened, as clearly shown in the 1942 Decree-Law 4.830.

New federal offices were established by the Decree-Law 2.024. Public servants staffed them at the federal level and in subsidiary agencies. The decree also identified the sources of financing for pro-

${ }^{5}$ The 1890 Criminal Code and the 1916 Civil Code must be mentioned in this connection. 
viders of social assistance. The new structure was coordinated by the Children's National Department (DNC), attached to the Ministry of Education and Health. This office had representation in the National Council for Social Service (CNSS) and was responsible for coordinating actions and policies related to children and adolescents. The new structure was designed as a national system. State Councils and Children's State Departments should be organized. Financial resources for the planned actions should be provided through the National Fund for the Protection of Children. The Decree-Law 3.799 also determined the reorganization of the Sete de Setembro Institute. The Assistance to Minors Service (SAM) then created was responsible for planning and coordinating actions related to internment of children and adolescents in charge of the Minors' Court.

The widening of the field of action afforded to private institutions resulted from one provision inserted in the Decree-Law 4.830. The first article authorized the Brazilian Legion for Social Assistance (LBA), recently created by Vargas's wife, Darcy Vargas, to act as a public sphere to promote cooperation and consultation between the federal government and private entities specialized in social services. Hence the new structure incorporated functions that in the 1930s were ascribed to CNSS.

LBA's financing came from two sources. The first was the monthly contribution corresponding to $0,5 \%$ of the monthly share paid by employees to Retirement and Pension Institutes (IAPs) and Funds (CAPs). The second were the monthly quotas paid by the federal government and the employers, whose amounts were equivalent to the total of employee contribution. ${ }^{6}$ With this financial backing, and with the help of the states' "first ladies", Darcy Vargas expanded the action of LBA throughout the country. The organization became the active center in planning and providing social assistance services either directly or through agreements with private entities. New financing sources were created in the 1950s. The 1951 Law 1.493 authorized institutions in charge of social services to receive yearly subventions and other eventual contributions to be used in their actions and acquisition of equipment and property. The 1959 Law 3.577 exempted institutions recognized as public utility entities from the contribution due by employers to Retirement and Pension Institutes and Funds. ${ }^{7}$

Thus, according to the prevailing legal framework, in the middle of the 20th century the Brazilian State counted mainly with private organizations for the provision of shelter services for children and adolescents, as well as other kinds of social assistance to this group. The number of such organizations grew rapidly especially in the southeast, given the access to significant financial resources and the role they played in decision-making processes in the CNSS and in the implementation of actions in the LBA. In the few studies focusing on children and adolescents institutionalization one can find information about the number of institutions in charge of providing shelter services. According to Rizzini (2007), in 1944 there were 33 homes in the roll of the SAM web. A decade later, the number reached 300. Rizzini and Rizzini found evidence showing that the care provided by these institutions deteriorated along the years. This development is related to the definition of the public to be assisted. According to Decree-Law 3.799, the public was formed by delinquents, thus emphasizing the repressive and correctional features of the actions. In the popular mind, those homes were prisons for "delinquent minors", "schools of crime" (Rizzini and Rizzini, 2004:34).

The legal and organizational structure for the provision of shelter services for children and adolescents above described prevailed until the beginning of the 1960s. At that time, two circumstances

\footnotetext{
${ }^{6}$ Before this decree, employers, employees and the federal government financed the Retirement and Pensions Institutes and Funds. In 1945 the Decree-Law 8.252 ruled that employees were exempt from this contribution. Employers had to transfer to LBA the amount of $0,5 \%$ of the payroll. The federal government was responsible for depositing the same amount.

${ }^{7}$ This exemption was canceled by the 1977 Decree-Law 1.572, but restored by the 1988 Federal Constitution (article 195). The 2009 Law 12.101 authorized the exemption of all social contributions for the institutions which received the Beneficent Entity for Social Assistance Certificate.
} 
gave place to the first significant turning point. The first was the evident inefficiency of the services provided by the State, described as a crisis. The second was the emergence of new social and political actors, who called for the reshaping of the policy. This context will be described in the next section.

\section{DECISIONS MADE DURING THE VARGAS YEARS: FEEDBACK EFFECTS ON THE MILITARY REGIME AND ON THE NEW REPUBLIC}

The crisis leading to the first turning point in the policy aiming at protecting children and adolescents began in the late 1950s. Connected to the negative public image of SAM, such crisis opened the way to a national debate concerning alternatives to the existing model built the previous decade. The Children's Rights Declaration approved by the General Assembly of the United Nations in 1959 inspired proposals of change publicized by social institutions and experts in the field. Despite the authoritarian nature of the regime the ongoing debate influenced decisions made by the government. But the changes were small given the impact of feedback effects of previous decisions in the actual management and resource capabilities inherent to the existing system, variables that decision-makers had to take into account. There were also in play interests of different political actors. New management rules were not implemented.

Among the first changes adopted by the military government was the creation of the National Foundation for the Welfare of Minors (Funabem). According to the 1964 Law 4.513, it replaced the SAM. The new structure was responsible for conceiving and coordinating the implementation of a National Policy for the Welfare of Minors (PNBEM), following norms established by a National Council in charge of making decisions for this field of public action. Same as seen in the 1927 Juvenile Code and the CNSS, the membership of this new council favored the private institutions: six representatives of the government, one representative of the National Order of Lawyers, three experts in the field of social assistance to children and adolescents, twelve representatives of private institutions, among them the LBA.

The changes introduced by the PNBEM in the actions aiming at protecting children and adolescents were seen in different levels. In the normative level it set the grounds for altering provisions related to the legal treatment of delinquents. The minimum legal age for criminal responsibility was raised to 18 years (1967 Law 5.258; 1968 Law 5.439). The 1967 Decree-Law 229 regulated adolescent labor. The 1979 Law 6.697, the new Juvenile Code, recognized the right that children and adolescents have to family and communitarian life.

This normative progress did not reflect in the reorganization of the shelter services that persisted unable to provide conditions to secure family and communitarian interaction for their public. Decisions made during the Vargas years set restrictions to the implementation of such an innovation, giving evidence to the influence of feedback effects mentioned by Pierson (1993). There was lack of bureaucratic expertise required for planning the changes in routines and procedures. The available material and financial resources were not enough to alter the prevailing bureaucratic and behavior patterns. It deserves mentioning that, at that time, the Brazilian social security system was in process of change, with negative impact on the directives for social assistance.

Among decisions that changed the social security system deserve mentioning the creation in 1966 of the National Institute of Social Security (INPS) which integrated six separated Retirement and Pension Institutes (IAPs), and the extension of social security coverage to professional groups until then excluded from the system, among them rural workers. From another perspective, one positive aspect of these changes was the restriction of the public eligible for social assistance protection. In the new institutional context, LBA's sphere of action was diminished and the institution lost power. The financial resources granted by legislation passed in the 1940s were reduced in the new structure. 
This happened with the 1966 Law 5.107 that established the employer's contribution to the Unemployment Compensation Fund (FGTS). As a result, funds to finance the actions developed by LBA and associated institutions were reduced to public subventions, endowment money and eventual revenue. Three years later the 1969 Decree-Law 593 reduced even further the importance of LBA now identified as a foundation (FLBA) with limited responsibilities, that is, to provide assistance, together with FUNABEM, to groups outside the coverage of "other systems", meaning mainly the INPS. The Ministry of Social Security and Assistance, created in 1974, was the manager of social services to be granted to workers registered in INPS rolls. In 1977, the National System of Social Security and Assistance (Sinpas) was organized, according to the Law 6.439. At this moment, the functions of LBA Foundation (FLBA) were expanded to include the provision of additional assistance to INPS insured and to people assisted by the National Medical Institute of Social Security (Inamps).

The consequence of decisions made during the military regime resulting in the organization of an expanded social security system, widening the coverage first envisioned by the "legislated citizenship" (cidadania regulada) (Santos, 1979) was the reduction of the potential public requiring social assistance policies. This public became the population outside the formal labor market, including those who could not find a place therein for different reasons. A subsidiary consequence was the reduction of responsibilities and resources until then allocated to LBA.

When shelter services for children and adolescents are considered, the conclusion is that organizational and management changes were minor. It deserves mentioning the systematization of procedures to be followed in agreements joining Funabem and private institutions. The principles then settled embodied a response to pressure coming from organized groups. According to these principles, the agreements should: a) give priority for programs aiming at the integration of the assisted in the community, emphasizing assistance to the minor's family or his/her reception in foster homes; b) promote the establishment of public institutions planned to reproduce features similar to ones found in family life; c) with this same goal in mind, promote adapting changes in existing private institutions.

According to Rizzini and Rizzini (2004), following these principles, 100 agreements were signed by the federal government between 1966 and 1973. At the state level, the same sort of initiatives began in 1967, when the first State Foundation for the Minor's Welfare (Febem) was established. This model of social care expanded rapidly in the states of the Brazilian federation, repeating the 1940s movement when LBA was created.

However, little was done in public and private institutions to promote the right to family life. Feedback effects were clearly operating, that is, lack of cognitive and technical capabilities in the planning of the required actions, lack of political will to create them. The public institutions then established became worse versions of the houses organized under the ruling of the 1927 Juvenile Code. Each received hundreds of children and adolescents and pretended to be able to perform all tasks and actions required by the rules regulating shelter homes. According to Rizzini and Rizzini (2004), the organizational expansion of coverage coincided with the intensification of the institutionalization option.

The persistence of the same old patterns in the provision and management of shelter services, despite the prescribed in the 1979 Juvenile Code, kept active social mobilization focusing on the issue, especially during the 1980s manifestations for the return to democracy. New actors entered the national stage. Among them deserve mention the National Movement of Boys and Girls Street Dwellers, organized in 1985, the National Front for the Defense of Children and Adolescents' Rights and the Constituent Child's National Committee, both established in 1986. The movement helped to publicize among Brazilians the profile of children and adolescents as legitimate political players 
and citizens with rights. The National Front and the National Committee acted in view of mobilizing institutions and organizations to present the National Constituent Assembly a new approach to childhood and youth to support legislation pertaining their social identity and rights.

The culmination of such mobilization is found in the innovations introduced by the 1988 Federal Constitution in the chapter focusing on the care and protection to be given to children and adolescents. It was then established that the protection of recognized rights of children and adolescents is an absolute priority for family, society and the State. According to article 227, children and adolescents are to be protected from all manifestations of negligence, discrimination, degradation, violence, cruelty and oppression. Families are the subject of "especial protection" to be secured by the State. In the spirit of this new approach, the 1988 Constitution introduced the principle of compulsory public schooling at the elementary level. ${ }^{8}$ The provision of elementary schooling became a joint responsibility of the three levels of government (Union, states and municipalities). The model of intergovernmental management systems was established for the provision of health and social assistance services for all citizens, the National Health System (SUS) and the National Social Assistance System (Suas).

Following the promulgation of the 1988 Federal Constitution new political directives were added to the policy for children and adolescent protection. In 1990 the Brazilian Congress ratified the International Children's Rights Convention, approved by the United Nations General Assembly in 1989. In the same year the Child and Adolescent Statute (ECA) was promulgated. According to principles inspiring the Constitution and the said convention, the statute defined the terms of "integral protection" to be secured for children and adolescents. The institutions responsible for accomplishing the required actions were identified: the Guardianship Council (Conselho Tutelar), municipal, state and federal councils for the protection of child and adolescent rights, the Child and Youth Court (Juizado da Infância e da Juventude), the Public Defender's Office (Defensoria Pública), the Prosecuting Attorney for Protection of Child and Youth (Promotoria da Infância e da Juventude) and the executive offices in charge of coordinating and implementing public policies, including the ones related to social assistance.

The means to secure formal compliance to the principle of integral protection are called "protective measures", among them the institutional shelter. The option for institutional shelter is classified as "exceptional", to be adopted only in extreme cases of violation of rights. It should last two years at the most. During this period the public authorities in charge of the policy are expected to actively promote the conditions for the safe return of the child or adolescent to his/her family. Moreover, the shelter is to be provided in small units, whose routines are planned to be similar to those found in family life. The shelter must be available in or near the area of residence of the assisted. This model is perhaps one of the main innovations brought by the ECA.

According to the new legislation, beginning in the new Republic, there were changes in the federal organization in charge of policies aiming at protecting children and adolescents. During Collor administration, the 1990 Law 8.029 altered the status of Funabem, now changed into a foundation, the Brazilian Center for Childhood and Youth (FCBIA). In 1991, the National Council for Child and Adolescent Rights (Conanda) and the National Fund for Child and Adolescent were created (Law 8.242).

Like the councils already created, Conanda includes governmental and non-governmental representatives. However, in this case, the law prescribed equal number of representatives for each group. In

\footnotetext{
${ }^{8}$ Given the potential impact on shelter services, it deserves mentioning here legislation passed in the 2000s: the extension to nine years of the period defined as public and compulsory elementary schooling (2006 Law 11.274); the extension of public schooling to preelementary school years (Constitutional Amendment n. 53/2006).
} 
2004 the number was set in fourteen. The responsibilities given to this council annulled any relevance that FCBIA might still have in decision-making related to assistance to children and adolescents. Among those responsibilities should be mentioned the definition of the general principles guiding the national policy for the protection and care for children and adolescents and the monitoring of actions aiming at promoting the required institutional reorganization of the web of related services. The council could also recommend organizational changes in public and private providers of assistance to children and adolescents.

Conanda was linked to the Human Rights Office of the Presidency of the Republic (SDH-PR), acting under the coordination of the National Office for the Promotion of Rights of Children and Adolescents. According to priorities set in an international agenda, incorporated in the Rights of Children's Convention and in the ECA, ${ }^{9}$ under Collor administration this office became the executive arm of Conanda, in charge of coordinating all related actions.

Despite the responsibilities ascribed to Conanda as well as the spheres of action included within its institutional sphere of competence, during the first half of the 1990s there were little if any changes in the structure and management of the public policy for children and adolescents' protection and care. Among the factors that may explain this inertia deserve mentioning the lack of political and budget resources as well as of bureaucratic capabilities. These circumstances resulted from decisions made during the Vargas years, when public investment favored private institutions. The fact that in 1995 Conanda still did not count on a regular administrative structure adds an evidence to the persistent influence of those factors (Conanda Resolution n. 40).

The national policy for social assistance was also under review. The organizational changes required for the implementation of ECA's provisions depended on decisions made at a higher level. The new model was devised in the 1993 Law 8.742, known as the Organic Law for Social Assistance (Loas). This law created the National Council for Social Assistance (CNAS), which replaced the CNSS.

In the new legal and organizational model, private institutions lost resources and power: first, because of the defined membership of CNAS, that is, nine representatives of the government and nine representatives of civil society, among those one representing the assisted public, one the workers in the field of social assistance, the remaining representing private institutions; second, because of the extinction of FLBA in 1995; third, because of the expansion and consolidation of a professional state bureaucracy, trained in the provision of social assistance. This last point is the focus of the next section.

\section{SHELTER SERVICES: THE PROCESS OF IMPLEMENTATION OF ECA'S DIRECTIVES FOR THEIR PROVISION AND MANAGEMENT}

The formation of a state bureaucracy trained in social assistance and the restructuring of related services began in the first Fernando Henrique Cardoso's administration, within the sphere of the Ministry for Social Security and Assistance. Unlike the structure created in 1974, and through the Secretary for Social Assistance, the Ministry became the leading coordinating center of the national policy for social assistance that, thus far, was the realm of the FLBA and of the Ministry of Social Welfare, now extinct. During the second Fernando Henrique's administration, the creation of the State Secretary for Social Assistance, with status equivalent to a ministry, expanded the formal jurisdiction of social assistance policies.

\footnotetext{
${ }^{9}$ The said convention was approved by the United Nations General Assembly in 1989 and endorsed by the Brazilian Congress in 1990 (Legislative Decree 28). It was promulgated by the 1990 Decree 99.710.
} 
Under the coordination of the two secretaries, and according to constitutional provisions and the Loas, the organizational foundations for the implementation of a truly national social assistance policy were established. The leading directives for the organization of a Decentralized and Participative System of Social Assistance were detailed in the 1997 and 1998 versions of guides containing the basic operational norms to orient public managers in charge of the task. According to these norms, intergovernmental managing committees were established and the responsibilities of each level of government in the provision and financing of the services were clearly specified, as well as the procedures for the transfer of federal and state financial resources to municipalities.

However, it was during Luis Inácio Lula da Silva - Lula's and Dilma Roussef's administrations that the decisive changes in the capabilities of a professional state bureaucracy able to manage material and financial resources destined to social assistance actions took place. Unlike the precedent administrations, Lula's and Dilma's gave high priority to social policies, including social assistance (Bichir, 2015). A major step was the creation in 2004 of the Ministry of Social Development and Fight against Hunger (MDS). In this new political and organizational context, there flourished the ideal publicized during the 2003 Fourth Social Assistance National Conference, embodied in the 2004 National Policy for Social Assistance (PNAS), that is, social assistance policies must be provided as a citizenship right, never as a philanthropic option.

The main thrust in the realization of this ideal came in 2005, when the National System of Social Assistance (Suas) was fully organized according to procedures and routines systematized in the third version of the operational guide. In this new bureaucratic context there were given the conditions favoring the production of knowledge focusing on the provision and management of social services, including the testing and implementation of adequate public structures for this purpose.

In what the restructuring and management of the services related to provision of shelter for children and adolescents are concerned, it is important to point out that changes in policies designed for social assistance both influenced and were influenced by changes in policies designed for the protection and care of children and adolescents. In the years 2004 e 2005 Conanda sponsored debates focusing on the challenges found in the way of fully realization of all of ECA provisions. As a result, in 2006 the Council and the CNAS approved the National Plan for the Promotion, Protection and Defense of Child and Adolescent's Right to Family and Communitarian Life. According to Nery (2010), this plan set the conceptual parameters for the restructuring of social services, including the institutional shelter. The 2009 Joint Resolution $\mathrm{n}^{\mathrm{o}} 1$ approved by Conanda and CNAS summarized the directives for the provision of institutional shelter under the title Technical Guidelines: Institutional Shelter Services for Children and Adolescents. Summing up, almost two decades after the promulgation of ECA the influence of decisions made during the Vargas years could be superseded by new conceptual and technical approaches deriving from expertise built within the government and the related councils.

The Technical Guidelines offer detailed orientation for compliance to the principles which define institutionalization of children and adolescents as an exceptional measure of limited duration. They describe the sphere of action of each public structure required in the routine of the service. They emphasize the need to pursue all alternative courses of action before deciding for the institutionalization. They stress the planning of integral care for the child or adolescent and his/her family oriented by the permanent goal of creating conditions for the safe return of the assisted to family life. In the spirit of ECA's prescriptions, the Guidelines point to the end of "total institutions": the institutional shelter and foster homes must receive at the most 20 or 10 children or adolescents, respectively. They must function as "incomplete institutions", that is, to perform all the prescribed functions, they are connected to a web of external, public structures and the technical staff work in permanent cooperation and interaction. 
Data provided by the 2014 Suas Census, fed by municipal and state managers of the social assistance policie, ${ }^{10}$ give evidence to the growth of coverage of the service as well as of improvements in management capabilities in this area of public action. (10) The selected data were taken from the category "shelter services" (acolhimento) and present features of institutions built for children and adolescents and for handicapped children and adolescents. The purpose of presenting these data can be summed up in these questions: governmental efforts geared to the provision and management of institutional shelter services for children and adolescents are congruent with parameters and goals set by ECA? The legacy of Vargas years has been superseded by new concepts and practice?

By the end of 2014, the total of shelter homes in the whole country was 2.791. Of this total, 2.748 received children and adolescents; 43 received handicapped children and adolescents. In the last group only one was state managed; only 11 were opened after the creation of Suas. ${ }^{11}$ The majority of the total of 2.748 shelter homes which receive children and adolescents are private institutions $(51,2 \%)$. Municipal and state governments are in charge of the remaining: 48\% and 0,7\%, respectively.

Of the total shelter homes available for children and adolescents, 2.400 (87,3\%) were opened after ECA's promulgation. Graphic 1 shows the distribution of shelter homes by their legal jurisdiction (municipal government, state government, non-governmental).

GRAPHIC 1 SHELTER HOMES FOR CHILDREN AND ADOLESCENTS BY DATA OF OPENING (MEDIA) (N=2.400)

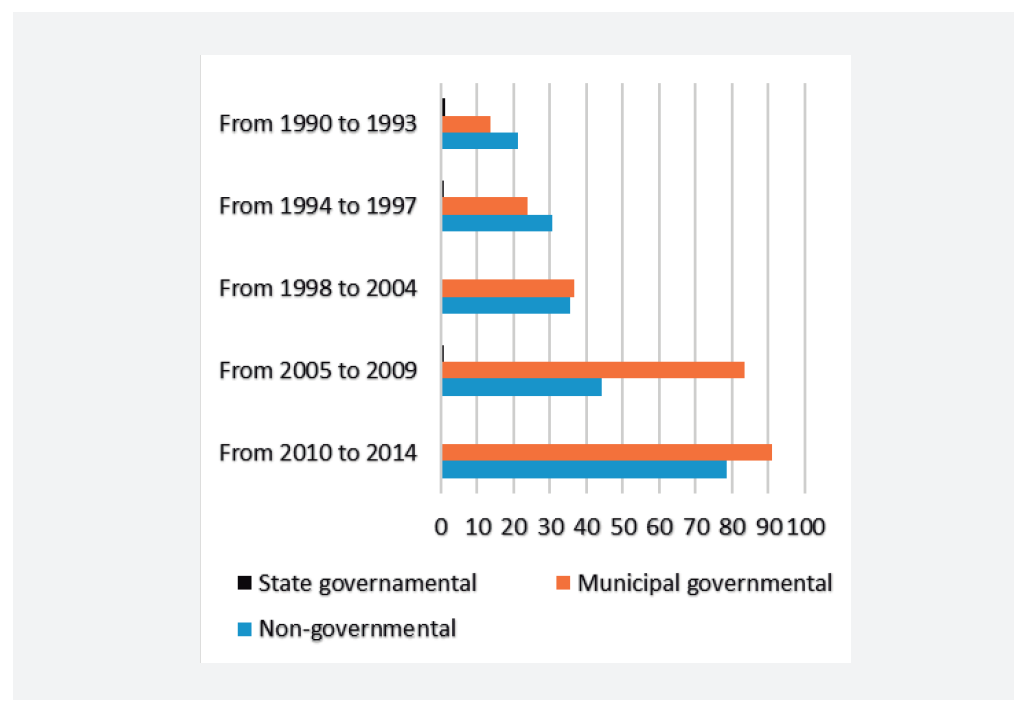

Source: MDS 2014 Census Suas.

\footnotetext{
${ }^{10}$ The census is yearly sponsored by MDS, with the cooperation of state and municipal SUAS managers in charge of registering routine data. The present analysis is based on the following questions: UF, ident_15, q1, q2, q5, q15c_1 a q15c10, q22_1 a q22_8.

${ }^{11}$ This development may be explained by one general directive of the National Policy for the Integration of Handicapped Persons, that is, segregation must be avoided in every action aimed at this group (1989 Law 7.853).
} 
GRAPHIC 2 NON-GOVERNMENTAL, MUNICIPAL GOVERNMENTAL, STATE GOVERNMENTAL SHELTER HOMES FOR CHILDREN AND ADOLESCENTS, BY DATA OF OPENING (\%) $(\mathrm{N}=1.408,1.320$ AND 20, RESPECTIVELY)

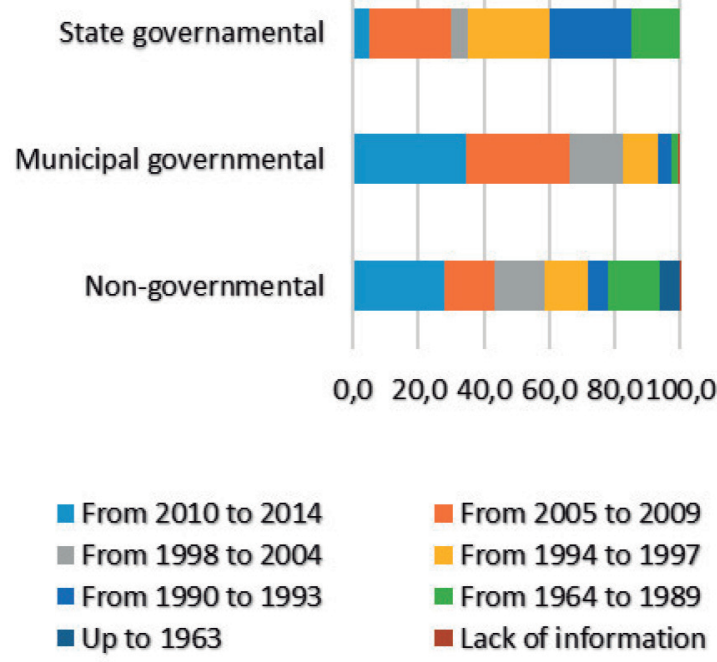

Source: MDS 2014 Census Suas.

GRAPHIC 3 NON-GOVERNMENTAL, MUNICIPAL GOVERNMENTAL AND STATE GOVERNMENTAL SHELTER HOMES FOR CHILDREN AND ADOLESCENTS: BRAZIL, NORTH, NORTHEAST, MIDWEST, SOUTHEAST AND SOUTH REGIONS (\%) (N=1.335, 714, 233, 337, 129, 2.748, RESPECTIVELY)

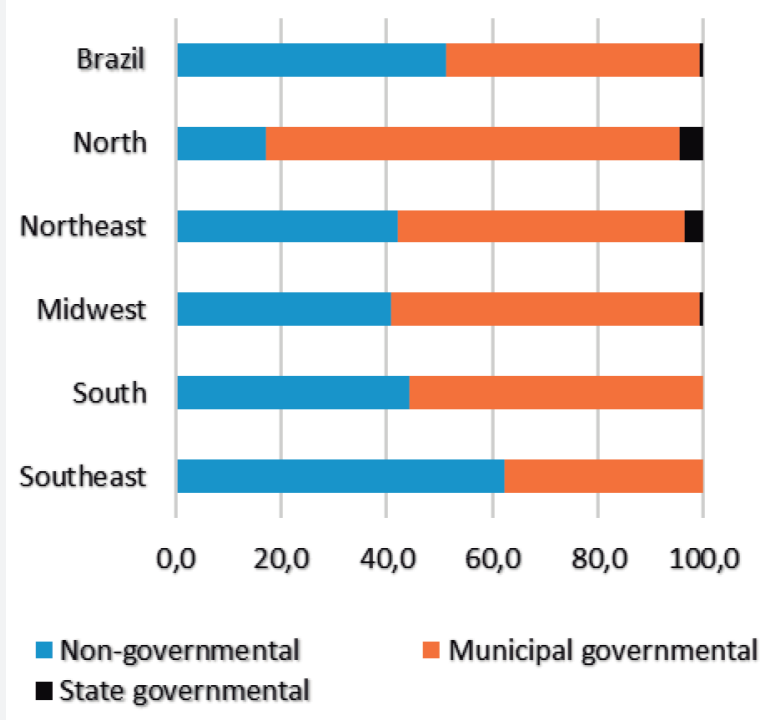

Source: MDS 2014 Census Suas. 
Along the recent development of social assistance policies aimed at protecting children and adolescents, one verifies the growing governmental emphasis on the expansion of the Institutional Shelter Service for Children and Adolescents. Graphic 1 shows that the annual average of opening of shelter homes raised from 36 in the years 1990-93 (the period ranges from ECA's promulgation to Loas's promulgation) to 128,8 in the years 2005-09 (the period ranges from the creation of Suas to the publication of the Technical Guidelines), reaching the high of 169,6 in the years 2010-14 (Dilma Roussef's first administration). The chart also shows that since the creation of MDS in 2004, there was a change in the legal identity of shelter services providers. Up to that moment, the number of non-governmental institutions predominated. The strengthening of a professional public bureaucracy and the securement of regular and expanding budget for social assistance granted by the federal government to municipal governments led this level of government to assume the leading role in the provision of shelter facilities.

The growth of municipal investment is also shown in graphics 2 and 3 . The first presents in percentage of the total of shelter homes opened in selected periods the contribution of state and municipal governments and private entities. The chart shows that $66 \%$ of shelter homes opened by municipal governments were established under Suas general coordination. The number is higher than the $43,5 \%$ of non-governmental and the $30 \%$ of state governmental homes opened in the same periods. Graphic 3 shows predominance of municipal investment in every region of the country, exception made to the Southeast. There is a historical predominance of private institutions in this region. The concentration of public investment in the remaining regions is an evidence of decisions made by the professional bureaucracy in charge of the policy aiming at securing greater equanimity in the provision of shelter services throughout the national territory, with or without the contribution of private institutions.

Graphics 4 and 5 systematize two other major improvements in the provision and management of shelter services related to the number of assisted per shelter and the duration of staying in the facility. To round the total numbers, the graphics take into account the number of homes registering at least one assisted person and the number of assisted in shelter homes for children and adolescents and shelter homes for handicapped children and adolescents.

\section{GRAPHIC 4 NON-GOVERNMENTAL, MUNICIPAL AND STATE GOVERNMENTAL SHELTER HOMES FOR CHILDREN AND ADOLESCENTS AND FOR HANDICAPPED CHILDREN AND ADOLESCENTS BY NUMBER OF ASSISTED BRACKETS (\%) ( $\mathrm{N}=1.379,1229,20, \mathrm{E} 42$, RESPECTIVELY)}

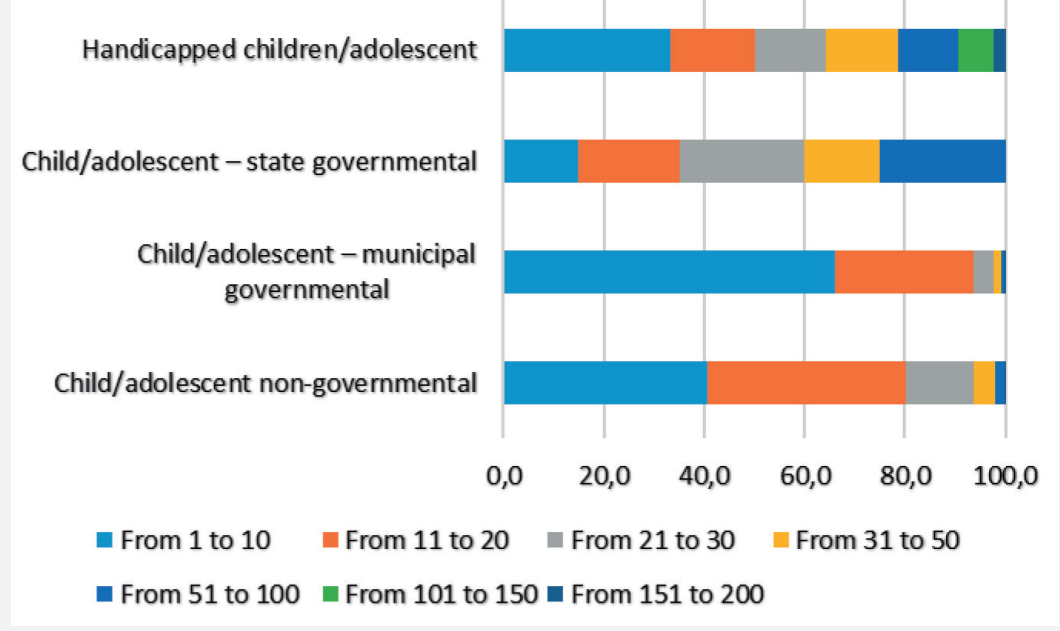

Source: MDS. 2014 Suas Census. 
Graphic 4 shows that the goal to put an end to institutions in charge of large numbers of people is succeeding: $85,6 \%$ of the registered 2.670 shelter homes assist less than 20 children and adolescents. The best performance is found among municipal shelter homes ( $93,7 \%$ of the total); the worse is found among the state institutions (35\%). However, there remain features of the historical legacy of this social service: 40 homes for children and adolescents and 8 for handicapped children and adolescents still register more than 50 assisted. Of the total of 48,11 are the shelter for more than 100 people, a common situation in the decades before ECA.

GRAPHIC 5 CHILDREN AND ADOLESCENTS AND HANDICAPPED CHILDREN AND ADOLESCENTS REGISTERED IN NON-GOVERNMENTAL, MUNICIPAL GOVERNMENTAL AND STATE GOVERNMENTAL SHELTER HOMES BY DURATION OF STAYING, IN MONTHS (\%) ( $\mathrm{N}=\mathbf{2 0 . 2 6 2 ,}$ 11.756, 708 AND 1.510, RESPECTIVELY)

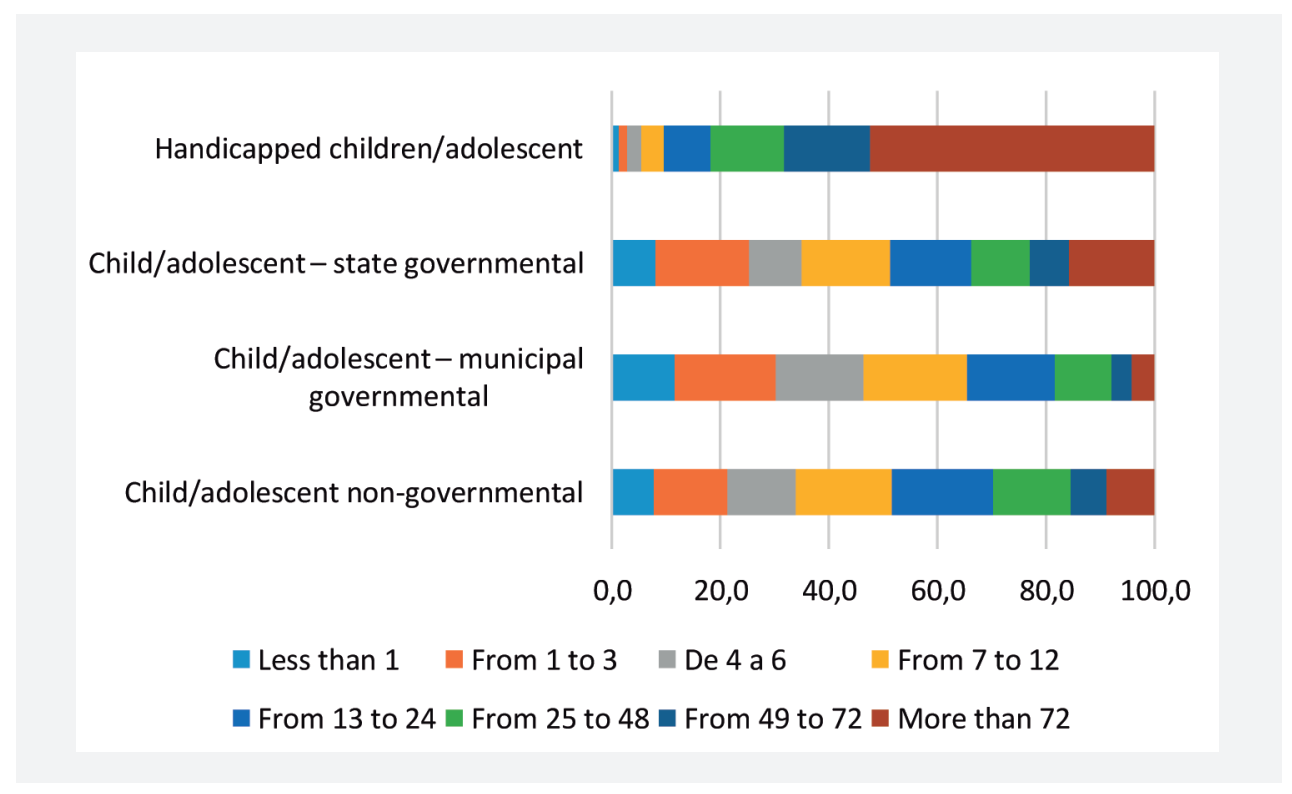

Source: MDS. 2014 Suas Census.

Graphic 5 gives evidence to improvements and to persisting challenges in the variable duration of staying in shelter homes. Of the total of 34.236 registered people in 2014, 71,8\% lived less than two years in the homes. These data lead to the conclusion that the time limit for the maintenance of such protective measure as determined by ECA was not secured for $28,2 \%$ of children and adolescents affected by this measure.

The data show that the best performance in the variable duration of staying is found among municipal governmental homes for children and adolescents $(81,7 \%$ of the public registered were residents for less than two years). The majority of these facilities were opened after the creation of Suas. The worse performance is found among shelter homes for handicapped children and adolescents: only $18,2 \%$ reached the goal prescribed by ECA. As already mentioned, the majority of facilities for this group was opened before the creation of Suas. 


\section{CONCLUSION}

The historical development of shelter services for socially vulnerable children and adolescents within the wider scope of policies devised for protecting this group provides evidence to analytical approaches favored by historical institutionalism, especially the strategic role played by professional bureaucrats in the formulation and implementation of public policies towards more organizational dynamism and less institutional inertia. The identified institutional inertia resulted from decisions made during the Vargas years. According to Pierson (1993), the persistent influence over later decisions works through two mechanisms of feedback effects, the first being the control of resources and incentives then given to private actors to the detriment of the public bureaucracy, the second being the cognitive effects of those decisions on the actors in play.

The analysis of such development has shown that policy changes may come from different sources. Public pressure and contributions of social actors impelled significant turning points in the political conceptions of care and protection to be secured by the State to children and adolescents. The new ideals and goals were embodied in the 1979 Juvenile Code and in ECA. However, previous decisions created obstacles to innovation, especially those required to secure to children and adolescents living in shelter homes the right to family life. The difficulties are found, first, in the persistent presence in decision-making processes of political actors, the representatives of private institutions, who were consistently empowered during the Vargas years, second, in the lack of a professional public bureaucracy able to plan and manage resources towards reaching that goal.

Both conditions, that is, available resources and professional expertise became a reality in the field of social assistance by the middle of the 1990s. This area of governmental action was definitely strengthened during the 2000s when social assistance was firmly established as public policy and given the status of governmental priority. At that time, the professional bureaucracy at the federal level prevailed over the representatives of private institutions in the decision-making spheres of Suas and in the councils related to the protection and care of children and adolescents, especially the Conanda. This new body of professionals also managed enough resources to be used in the production of knowledge required for the implementation of ECA's provisions and for the management of the related services.

Despite the many improvements, there is still a sad legacy of the past: for almost $30 \%$ of children and adolescents subject to the protective measure of institutionalization the goal of returning to family life has not yet been reached; in almost $15 \%$ of shelter homes the number of residents is much higher than the prescribed by the Technical Guidelines. 


\section{REFERENCES}

BICHIR, Renata M. Capacidades estatais para a implementação de programas de transferência de renda: os casos de Brasil, Argentina e África do Sul. Brasília: IPEA, Texto para Discussão, n. 2032, 2015.

BRAZIL. Conselho Nacional dos Direitos da Criança e do Adolescente (Conanda). Resolução no 40, de agosto de 1995. Brasília, 1995. Available at: <http:// dh.sdh.gov.br/download/resolucoes-conanda/res1-a-99.pdf>. Accessed on: 30 Jan. 2016.

BRAZIL. Conselho Nacional dos Direitos da Criança e do Adolescente (Conanda); Conselho Nacional de Assistência Social (CNAS) Resolução Conjunta $n^{o}$ 1, de 18 de junho de 2009. Aprova o documento Orientações Técnicas: Serviços de Acolhimento para Crianças e Adolescentes. Brasília, 2009.

BRAZIL. Constituição da República Federativa do Brasil, de 1988. Available at <www.senado.gov.br/ legislacao/const/con1988/CON1988_05.10.1988/ CON1988.pdf> Accessed on: 10 Jan. 2016.

BRAZIL. Decreto-Lei $n^{\circ} 229$, de 28 de fevereiro de 1967. Altera dispositivos da Consolidação das leis do

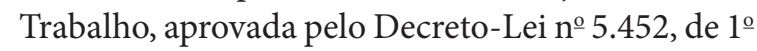
de maio de 1943, e dá outras providências. Available at: <www.planalto.gov.br/ccivil_03/decreto-lei/ del0229.htm>. Accessed on: 15 Jan. 2016.

BRAZIL. Decreto-Lei n⿳ํㅗㄴ 525, de 1o de julho de 1938. Institui o Conselho Nacional de Serviço Social e fixa as bases da organização do serviço social em todo o país. Available at: <www2.camara.leg.br/ legin/fed/declei/1930-1939/decreto-lei-525-1-julho-1938-358399-publicacaooriginal-1-pe.html>. Accessed on: 15 Jan. 2016.

BRAZIL. Decreto-Lei no 593, de 27 de maio de 1969. Autoriza o Poder Executivo a instituir uma fundação destinada a prestar assistência à maternidade, à infância e à adolescência. Available at: <www.planalto. gov.br/ccivil_03/decreto-lei/1965-1988/del0593. htm>. Accessed on: 15 Jan. 2016.

BRAZIL. Decreto-Lei $n^{\circ}$ 2.024, de 5 de agosto de 1940. Fixa as bases da organização da proteção à maternidade, à infância e à adolescência em todo o País. Available at: <www2.camara.leg.br/legin/ fed/declei/1940-1949/decreto-lei-2024-17-fevereiro-1940-411934-publicacaooriginal-1-pe.html>. Accessed on: 15 Jan. 2016.
BRAZIL. Decreto-Lei $n^{\text {o }} 3.799$, de 5 de novembro de 1941. Transforma o Instituto Sete de Setembro em Serviço de Assistência a Menores e dá outras providências. Available at: <www6.senado.gov.br/ legislacao/ListaPublicacoes.action?id=87272>. Accessed on: 15 Jan. 2016.

BRAZIL. Decreto-Lei no 4.830 , de 15 de outubro de 1942. Estabelece contribuição especial para a Legião Brasileira de Assistência e dá outras providências. Available at: <www.planalto.gov.br/ccivil_03/decreto-lei/1937-1946/Del4830.htm>. Accessed on: 15 Jan. 2016.

BRAZIL. Lei $n^{\circ}$ 1.493, de 13 de dezembro de 1951. Dispõe sobre o pagamento de auxílios e subvenções. Available at: <www.planalto.gov.br/ccivil_03/ leis/1950-1969/L1493.htm>. Accessed on: 10 Jan. 2016.

BRAZIL. Lei $n^{\circ}$ 3.577, de 4 de julho de 1959. Isenta da taxa de contribuição de previdência aos Institutos e Caixas de Aposentadoria e Pensões as entidades de fins filantrópicos, reconhecidas de utilidade pública. Available at: <www010.dataprev.gov.br/sislex/paginas/42/1959/3577.htm>. Accessed on: 10 Jan. 2016.

BRAZIL. Lei $n^{\circ}$ 4.513, de 1ํ de dezembro de 1964. Autoriza o Poder Executivo a criar a Fundação Nacional do Bem-Estar do Menor, a ela incorporando o patrimônio e as atribuições do Serviço de Assistência a Menores, e dá outras providências. Available at: <www.planalto.gov.br/ccivil_03/leis/1950-1969/ L4513.htm>. Accessed on: 10 Jan. 2016.

BRAZIL. Lei no 5.107, de 13 de setembrode 1966. Cria o Fundo de Garantia por Tempo de Serviço. Available at: <www.planalto.gov.br/ccivil_03/LEIS/ L5107.htm>. Accessed on: 10 Jan. 2016.

BRAZIL. Lei $n^{\circ}$ 5.258, de 10 de abril de 1967. Dispõe sobre medidas aplicáveis aos menores de 18 anos pela prática de fatos definidos como infrações penais e dá outras providências. Available at: <www.planalto. gov.br/ccivil_03/LEIS/1950-1969/L5258.htm>. Accessed on: 10 Jan. 2016.

BRAZIL. Lei $n^{\circ}$ 5.439, de 22 de maio 1968. Altera a Lei no 5.258 , de 10 de abril de 1967, que dispõe sobre medidas aplicáveis aos menores de 18 anos pela prática de fatos definidos como infrações penais e dá outras providências. Available at: <www. planalto.gov.br/ccivil_03/LEIS/1950-1969/L5439. htm>. Accessed on: 10 Jan. 2016. 
BRAZIL. Lei $n^{\underline{0}}$ 6.439, de $1^{\circ}$ de setembro de 1977. Institui o sistema Nacional de Previdência e Assistência Social e dá outras providências. Available at: <www.planalto.gov.br/ccivil_03/LEIS/L6439.htm>. Accessed on: 10 Jan. 2016.

BRAZIL. Lei $n^{\underline{o}}$ 6.697, de $1^{\text {o }}$ de outubro de 1979. Institui o Código de Menores. Available at: <www. planalto.gov.br/ccivil_03/leis/1970-1979/L6697. htm>. Accessed on: 10 Jan. 2016.

BRAZIL. Lei $n^{\circ}$ 8.029, de 1990. Dispõe sobre a extinção e dissolução de entidades da administração Pública Federal, e dá outras providências. Available at: <www.planalto.gov.br/ccivil_03/leis/L8029cons. htm>. Accessed on: 10 Jan. 2016.

BRAZIL. Lei $n^{\circ}$ 8.069, de 13 de julho 1990. Dispõe sobre o Estatuto da Criança e do Adolescente e dá outras providências. Available at: <www.planalto. gov.br/ccivil_03/LEIS/L8069.htm\#art267>. Accessed on: 10 Jan. 2016.

BRAZIL. Lei $n^{0} 8.242$ de 11 de outubro 1991. Cria o Conselho Nacional dos Direitos da Criança e do Adolescente (Conanda) e dá outras providências. Available at: <www.planalto.gov.br/ccivil_03/LEIS/ L8242.htm>. Accessed on: 10 Jan. 2016.

BRAZIL. Lei $n^{\circ}$ 8.742, de 7 de dezembro de 1993. Dispõe sobre a organização da Assistência Social e dá outras providências. Available at: <www.planalto.gov.br/ ccivil_03/leis/L8742.htm>. Accessed on: 10 Jan. 2016.

BRAZIL. Presidência da República. Decreto $n^{-}$ 17.943-A, de 12 de dezembro de 1927. Consolida as leis de assistência e proteção a menores. Available at: <www.planalto.gov.br/ccivil_03/decreto/1910-1929/ D17943A.htm>. Accessed on: 15 Jan. 2016.

GOUREVITH, Peter. Politics in hard times: comparative responses to international economic crisis. Ithaca: Cornell University Press, 1986.

HALL, Peter. Policy paradigms, social learning, and the state: the case of economic policymaking in Britain. Comparative Politics, v. 25, n. 3, p. 275296, 1993.

NERY, Maria A. A convivência familiar e comunitária é direito da criança e do adolescente e uma realidade a ser repensada pela escola. Cad. Cedes, v. 30, n. 81, p. 189-207, 2010.

PIERSON, Paul. When effect becomes cause: policy feedback and political change. World Politics, v. 45, n. 4, p. 595-628, 1993.

RIZZINI, Irene. O século perdido: raízes históricas das políticas públicas para a infância no Brasil. São Paulo: Cortez, 2007.

RIZZINI, Irene; RIZZINI, Irma. A institucionalização de crianças no Brasil: percurso histórico e desafios do presente. São Paulo: Loyola, 2004.

SANTOS, Wanderley G. Cidadania e justiça: a política social na ordem brasileira. Rio de Janeiro: Campus, 1979.

SKOCPOL, Theda. Protecting soldiers and mothers: the political origins of social policy in the United States. Cambridge; London: The Belknap Press of Harvard University Press, 1992.

SOARES, Janine B. A construção da responsabilidade penal no adolescente no Brasil: uma breve reflexão histórica. Revista do Ministério Público, v. 1, n. 51, p. 257-285, 2003.

THELEN, Kathleen; STEINMO, Sven. Historical institutionalism in comparative politics. In: STEINMO, Sven; THELEN, Thelen; LONGSTRETH, Frank (Ed.). Structuring politics: historical institutionalism in comparative analysis. Cambridge: Cambridge University Press, 1992. p. 1-32.

WEIR, Margareth; SKOCPOL, Theda. State structures and the possibilities for keynesian' responses to the Great Depression in Sweden, Britain and the United States. In: EVANS, Peter B.; RUESCHEMEYER, Dietrich; SKOCPOL, Theda. Bring the State back in. Cambridge: Cambridge University Press, 1999. p. 143-144.

\section{Geralda Luiza de Miranda}

Is an adjunct professor at the Political Science Department of the Federal University of Minas Gerais (UFMG). She has a doctoral degree in Political Science. E-mail: geraldaluiza@fafich.ufmg.br. 